CONTROL ENGINEERING 


\section{CONTROL ENGINEERING}

Theory, worked examples and problems

Ruth V. Buckley

Principal Lecturer

Department of Electrical and

Communication Engineering

Leeds Polytechnic 
(C) R. V. Buckley 1976

All rights reserved. No part of this publication may be reproduced or transmitted, in any form or by any means, without permission

First published 1976 by

THE MACMILLAN PRESS LTD

London and Basingstoke

Associated companies in New York Dublin

Melbourne Johannesburg and Madras

SBN 333197763

ISBN 978-1-349-03021-7

ISBN 978-1-349-03019-4 (eBook)

DOI 10.1007/978-1-349-03019-4

This book is sold subject to the standard conditions of the Net Book Agreement.

The paperback edition of this book is sold subject to the condition that it shall not, by way of trade or otherwise, be lent, re-sold, hired out, or otherwise circulated without the publisher's prior consent in any form of binding or cover other than that in which it is published and without a similar condition including this condition being imposed on the subsequent purchaser. 


\section{CONTENTS}

Preface vii

1. TRANSFER FUNCTIONS 1

2. BLOCK DIAGRAMS 14

3. SIGNAL FLOW GRAPHS 26

4. STEADY-STATE AND TRANSIENT RESPONSE 35

5. NYQUIST ANALYSIS AND STABILITY 47

6. THE BODE DIAGRAM $\quad 59$

$\begin{array}{ll}\text { 7. NICHOLS CHART ANALYSIS } & 76\end{array}$

8. THE ROOT LOCUS PLOT $\quad 85$

9. MISCELLANEOUS PROBLEMS 101

$\begin{array}{lll}\text { Appendix A Block diagram theorems } & 106\end{array}$

Appendix B M-circle data; N-circle data 109

$\begin{array}{lll}\text { Appendix C Root locus plots } & 110\end{array}$

$\begin{array}{ll}\text { Bibliography } & 112\end{array}$ 


\section{PREFACE}

The main object in producing this textbook is to provide a series of worked exercises and unworked problems, with answers, in control engineering topics. The general standard aimed at is that of an electrical or mechanical engineering first degree, or the Council of Engineering Institutions examinations in Control System Engineering (Section A of the new syllabus). A small number of the examples are suitable for H.N.C. and H.N.D. courses.

Each chapter is preceded by a brief introduction covering the essential points of theory relevant to the problems that follow and stressing the fundamental principle.

A selection of problems is taken from past examination papers set by the Institution of Electrical Engineers, the Council of Engineering Institutions and Leeds Polytechnic. In this respect, my thanks are due to the Council of Electrical Engineers, the Council of Engineering Institutions and the governing body of the Leeds Polytechnic, for permission to use questions taken from their examination papers, the solutions to which are my own responsibility.

The work is divided into eight main chapters, each dealing with specific aspects of the chosen control section, and an attempt has been made to cover a reasonably wide spread of subject material in the worked examples that follow.

The ninth chapter consists of miscellaneous problems that did not fit directly under the chosen chapter headings but that nevertheless the reader should find helpful in studying control engineering theory.

No attempt has been made to include analog or digital computer examples, since the author feels that these topics are sufficiently specialised to justify a book to themselves, and in fact there are several such good books on the market.

The author wishes to express her gratitude to the publishers for their many helpful suggestions and criticisms and to her colleagues, B. Mann and J.B. Stephenson, for their interest and support during the preparation of the book.

Leeds,

January, 1976

R. V. Buckley 